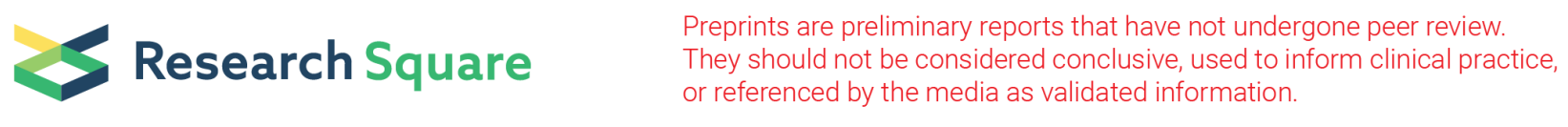

\title{
Clinicopathologic Factors Related to Post-Operative Outcome of Pituitary Adenoma: a Meta-Analysis
}

\author{
Tri Juli Edi Tarigan ( $\nabla$ Tri.judi@ui.ac.id) \\ Dr. Cipto Mangunkusumo National General Hospital, Universitas Indonesia \\ Hasan Ali Alhabsyi \\ Dr. Cipto Mangunkusumo National General Hospital, Universitas Indonesia \\ Juferdy Kurniawan \\ Dr. Cipto Mangunkusumo National General Hospital, Universitas Indonesia
}

\section{Research Article}

Keywords: Aggressive, clinicopathologic, pituitary adenoma, post-operative

Posted Date: October 22nd, 2021

DOI: https://doi.org/10.21203/rs.3.rs-953232/v1

License: (c) (i) This work is licensed under a Creative Commons Attribution 4.0 International License. Read Full License 


\section{Abstract}

Purpose: About $30 \%$ to $40 \%$ of patients with pituitary adenoma require surgery. About $25 \%$ to $40 \%$ of those who have had surgery will have an aggressive outcome. The purpose of this study was to see if certain clinicopathologic factors such as size, type/subtype, invasiveness, proliferative (ki67 , mitotic rate, and p53), and grade influenced the aggressiveness of postoperative pituitary adenomas.

Methods: The factors mentioned in the research objectives were examined as independent variables. Ten studies out of 736 were chosen. The 10 studies had 2727 participants and 632 cases. The monitoring lasted 3-11 years. The studies' quality ranged from fair to excellent.

Results: The results of the meta-analysis were: size $\geq 10 \mathrm{~mm}$ OR 1,79 (1,29-2,48), corticotroph OR 1,91 (1,41-2,58), invasive OR 3,67 (1,95-6,90), proliferative OR 4,78(3,61-6,32), Ki-67 $\geq 3 \%$ OR 4,13 (2,94-5,81), mitotic rate > 2 OR 3,91 (2,74-5,57), p53 positive OR 1,92 (1,28-2,90), and grade 2b OR $4,56(3,0-6,91)$.

Conclusions: Size, type/subtype, invasiveness, proliferative (ki-67, mitotic rate, and p53), and grade of postoperative pituitary adenoma influenced the postoperative aggressiveness outcome.

\section{Introduction}

Pituitary adenoma, also known as pituitary neuroendocrine tumor (PitNET) ${ }^{1,2}$ is a type of intracranial tumor that typically arises from the anterior lobe of the pituitary gland and accounts for $10-15 \%$ of all intracranial tumors. ${ }^{3,4}$ According to the Japan brain tumor registry center, $19.2 \%$ of 13,431 cases of brain tumors were histopathologically confirmed as pituitary adenoma. ${ }^{5}$ Pituitary adenoma was found to be prevalent in South Korea, with a prevalence of 62.9 cases per 100,000 people and an incidence of 26.1 cases per 100,000 people, according to a population-based study using data from the National Health Insurance. ${ }^{6}$ Data from the English city of Banbury shows 63 cases of pituitary tumors out of a total population of 89,334 people, with a population prevalence of 77 cases per $100,000 .^{7}$

About $60-70 \%$ of pituitary adenomas are prolactinomas that respond well to medical treatment, though about $10-15 \%$ require surgery. With indications of macroadenoma invading surrounding tissue accompanied by visual disturbances or clinically due to hormone hypersecretion that does not respond well to medical therapy, approximately $30-40 \%$ of patients with pituitary adenoma require surgical management. ${ }^{8,9}$ About $25-40 \%$ of patients who had surgery had unfavorable outcomes, such as local invasion, resistance to conventional therapy, a high recurrence rate, and metastases. ${ }^{10,11}$ Pituitary adenomas are malignant in about $0.2-0.5 \%$ of cases. While mortality occurs in approximately $28 \%$ of aggressive pituitary adenomas and $42.5 \%$ of pituitary carcinomas over the median of $11-12$ years. ${ }^{12,13}$ It is challenging and necessary to predict the nature of pituitary adenomas because early detection of potentially aggressive adenomas will lead to aggressive treatment, which is expected to improve patient outcomes.

The size of the adenoma, the type/subtype of the adenoma, the invasive nature of the adenoma (imaging), the proliferative nature of the adenoma (immunohistochemical examination (IHC) on $\mathrm{Ki}-67$, mitotic activity, and p53), adenoma grade, and novel biomarkers are some of the factors that are thought to be involved in the outcome of pituitary adenoma analyzed in the past studies. These factors require healthcare providers to have adequate imaging, surgery, and anatomical pathology (in this case, IHC examination) modalities to support pituitary adenoma patients' specific management. The European Society of Endocrinology (ESE) guidelines for the management of pituitary adenoma cases, on the other hand, include recommendations for $\mathrm{IHC}$ examination with a very low level of evidence. ${ }^{14}$

Previous studies that looked at the prognostic factors above came up with varying significance values. According to Trouillas $\mathrm{J}$ et al. ${ }^{15}$ and Asioli $\mathrm{S}$ et al. $^{16}$, when adenomas are classified as micro or macroadenomas, the odds ratio (OR) for an aggressive outcome is 3.2 consecutively (confidence interval $(\mathrm{Cl})=1.64-6.26)$ and $1.81(\mathrm{Cl}=1.099-2.979)$, respectively in macroadenomas. However, Raverot $\mathrm{G}$ et al. ${ }^{17}$ concluded that it lacked prognostic significance, with a hazard ratio $(\mathrm{HR})$ of $1.34(\mathrm{Cl}=0.65-2.76)$.

Atypical pituitary adenomas were classified as a special classification by the World Health Organization (WHO) in 2004 solely based on the adenomas' proliferative nature. ${ }^{18}$ However, it was later removed from the 2017 WHO classification since it did not provide patients with different prognostic values. ${ }^{19}$ This is because, as several studies have shown, assessing the level of aggressiveness of pituitary adenomas solely based on proliferative properties is insufficient; other clinical evaluations such as mass size and invasiveness are also necessary. ${ }^{15-20}$

Existing studies have found conflicting results regarding the prognostic value of pituitary adenoma type; according to Asioli $\mathrm{S}$ et al ${ }^{16}$, lactotrophs and corticotrophs have a worse outcome than other types, with $\mathrm{HR}$ of $2,968(\mathrm{Cl}=1,672-5,27)$ and $2,336(\mathrm{Cl}=1,233-4,426)$, respectively, whereas other studies found no difference in prognostic value in the type of adenoma. ${ }^{15,17,20}$ Although the data available to date is still limited, WHO emphasizes the high risk of aggressive pituitary adenoma in the five subtypes of pituitary adenoma. Sparsely granulated somatotroph adenoma, lactotroph adenoma in men, Crooke's cell adenoma, silent corticotroph adenoma, and pituitary-specific transcription factor 1 (Pit-1) positive adenoma are among the five subtypes. ${ }^{21}$

Another point of debate is the lack of consensus on the Ki-67 proliferative marker's threshold value. The percentages proposed range from $1.3-10 \% .22,23$ The majority of studies, however, use a $3 \%$ threshold. ${ }^{14}$ While a value of more than $10 \%$ is considered to be a sign of malignancy. ${ }^{23}$ All of these figures are only based on a limited number of case studies, a short observation period, or even expert opinions. 
According to the findings, there are still few studies examining the importance of assessing prognostic factors in postoperative pituitary adenoma. Also, no systematic study has been attempted to collect all the studies out there. The main aim of this study was to see if clinicopathological factors influence the aggressiveness of postoperative pituitary adenomas.

\section{Method}

This research is a systematic examination that collects data from both electronic and manual sources. This study's inclusion criteria were as follows:

1. Adult participants in observational studies

2. The study included subjects with pituitary adenoma who had undergone surgery and had histological data.

3. Studies looked at adenoma size, invasiveness, proliferative qualities, adenoma type, adenoma subtype, ki-67, p53, mitotic rate, and adenoma grade as independent variables.

4. The study looked at the relationship between independent variables and aggressiveness (recurrence or advancement to conventional therapy (surgery, medicine, and/or radiation)) of pituitary adenoma as early as one year after surgery.

The following were excluded:

1. Only certain patients with pituitary adenoma were included in the study.

2. The study only assessed less than three independent variables.

The study protocol was registered using PROSPERO.With the help of the Covidence device, the search was carried out. PubMed, CINAHL, Scopus, ProQuest, and Science Direct were used to conduct a literature search using electronic-based data sources. Manual searches are also conducted using reference lists and citations from related journals (snowballing), as well as other search engines such as Google Scholar and Global Index Medicus, the results of theses and dissertations through the online libraries of Indonesia's major universities, and contacting endocrinologists, particularly in the field of pituitary adenoma, through related semi-structured interviews.

The literature search employs keywords to represent each PICO element and is tweaked with MESHterms, truncation, and proximity signs to match the desired data source. Keywords that were used were (((post operative pituitary adenoma) OR (post surgical pituitary adenoma) OR (post surgical pituitary neuroendocrine tumor) OR (post operative pituitary neuroendocrine tumor)) AND ((size) OR (type) OR (subtype) OR (invasion) OR (proliferation) OR (ki67) OR (mitoses) OR (p53) OR (grade))) AND ((aggressive) OR (recurrence) OR (resistant) OR (progression)).

Data extraction for each study was completed with the help of Covidence and Excel, then grouped according to each independent variable, type, measurement estimation/conclusion, and study design, in which the information is presented in a tabular format later.

The Newcastle Ottawa Scale (NOS) is used to determine the quality of a study and the possibility of bias. Examined biases are baseline confounding, study participant selection bias, searching for missing data, and reported bias. The results of the assessments are tabulated and grouped according to the study's design. The study component's assessment results are then added together and concluded the quality of the study according to the score :

1. Between 7 and 9: good

2. Between 4 and 6: adequate

3. Between 1 and 3: poor

This evaluation will be used in concluding the study's findings. The study selection bias was assessed regarding how much data the independent variables had from the list of excluded studies. Two researchers worked independently on each stage of this systematic study. Any disagreements are worked out in collaboration with the third researcher. RevMan 5.4 was used to carry out the quantitative synthesis. If the $I^{2}$ value is greater than $60 \%$, heterogeneity is considered significant. A narrative review is performed if data is unavailable or cannot be extracted, or heterogeneity is too high.

\section{Result}

The literature review took place between July 21 and August 9, 2020. In total, 736 studies were found, with limitations applied to each database in the form of studies in humans and adults, duplication of studies eliminated, and titles and abstracts screened. 568 studies were agreed to be excluded, leaving 22 studies. The search was continued by reading the full text of 22 studies. Both researchers agreed that 12 studies should be eliminated for the reasons listed in table L1. In the end, ten studies were analyzed qualitatively and quantitatively. Figure L1 illustrates the detailed search flow.

The studies took place in Europe, Asia, and the United States. There were a total of 2727 people in the study, with 632 people in the case group. The majority of studies had a monitoring period of 3 to 5 years, but one study had a monitoring period of up to 11 years. Table 1 lists the characteristics of each selected study.

All of the studies were of a good to an excellent standard. The poor-quality studies are: 
1. Gejman et al. ${ }^{24}$ : too many sample candidates were excluded due to a lack of data.

2. Trouillas et al. ${ }^{15}$ : about $45 \%$ of the sample candidates were excluded due to a lack of data.

3. Hasanov et al. ${ }^{25}: 18 \%$ of subjects dropped out without explanation.

4. Raverot et al. ${ }^{17}$ : has a poor adequacy component of follow-up because more than $30 \%$ of subjects dropped out without adequate explanation of their outcome.

Tables 2 and 3 describe the study's quality in great detail.

Each independent variable on the aggressiveness of postoperative pituitary adenoma was subjected to meta-analysis. In the studies that looked at it:

1. Adenoma's size: The meta-analysis of the case-control study revealed that a size of $\geq 10 \mathrm{~mm}$ was significantly more aggressive, with an OR of 1.79 (1.29-2.48). (figure 1). Meanwhile, in a cohort meta-analysis study, the size $\geq 10 \mathrm{~mm}$ was significantly more aggressive, with an HR of 1.79 (1.08-2.96). (figure 2).

2. Adenoma type: Corticotroph-type adenoma was significantly more aggressive, with an OR of 1.88 (1.39-2.55), while the somatotroph-type adenoma was significantly less aggressive, with an OR of $0.65(0.49-0.88)$ (Fig. 3).

3. Invasive trait: Invasive adenomas were found to be significantly more aggressive, with an OR of 2.59 (2.06-3.26)(figure 4).

4. Proliferative trait: Proliferative adenomas were found to be significantly more aggressive, with an OR of 4.78 (3.61-6.32)(figure 5).

5. Ki-67: With an OR of 4.13 (2.94-5.81), the meta-analysis revealed that adenomas with $\mathrm{Ki}-673 \%$ were significantly more aggressive (figure 6 ).

6. Mitosis rate: Mitotic rates $>2$ were found to be significantly more aggressive, with an OR of 3.13 (1.19-8.20)(figure 7).

7. p53: Aggressiveness has been found in adenomas with positive p53 in some studies. P53-positive adenomas were found to be significantly more aggressive, with an OR of $1.92(1.28-2.90)$ (figure 8).

8. Adenoma grade: Grade 2b adenomas were found to be significantly more aggressive, with an OR of 4.56 (3.00-6.91)(figure 9). 
Table 1

Basic characteristics of selected studies

\begin{tabular}{|c|c|c|c|c|c|c|c|c|c|}
\hline No. & Study, Year & $\begin{array}{l}\text { Number } \\
\text { of } \\
\text { Subjects } \\
\text { (Case) }\end{array}$ & Study Design & $\begin{array}{l}\text { Data } \\
\text { Collection } \\
\text { Period }\end{array}$ & Country & Outcome & $\begin{array}{l}\text { Observation } \\
\text { Period }\end{array}$ & Assessed Variable(s) & Funding \\
\hline 1 & $\begin{array}{l}\text { Hsu et al26, } \\
1993\end{array}$ & $62(30)$ & Case-control & $\begin{array}{l}1982- \\
1992\end{array}$ & USA & Recurrence & $\begin{array}{l}\text { Mean } 7.3 \\
\text { year }\end{array}$ & $\begin{array}{l}\text { Size, invasiveness and } \\
\text { postoperative residue }\end{array}$ & $\begin{array}{l}\text { Public } \\
\text { health } \\
\text { service grant }\end{array}$ \\
\hline 2 & $\begin{array}{l}\text { Gejman et } \\
\mathrm{al}^{24}, 2008\end{array}$ & $55(24)$ & Case-control & $\begin{array}{l}1984- \\
2005\end{array}$ & USA & Progression & 5 year & $\begin{array}{l}\text { Size, invasiveness, Ki- } \\
67, \text { p53, and } \\
\text { postoperative residue }\end{array}$ & $\begin{array}{l}\text { University } \\
\text { and } \\
\text { government } \\
\text { scholarships }\end{array}$ \\
\hline 3 & $\begin{array}{l}\text { Matsuyama } \\
\text { et } \mathrm{al}^{27} \\
2012\end{array}$ & $39(12)$ & Case-control & $\begin{array}{l}2001- \\
2009\end{array}$ & Japan & Progression & $\begin{array}{l}\text { Mean } 46.1 \\
\text { month }\end{array}$ & $\begin{array}{l}\text { Size, invasiveness, } \mathrm{Ki}- \\
67 \text {, and postoperative } \\
\text { residue }\end{array}$ & - \\
\hline 4 & $\begin{array}{l}\text { Trouillas et } \\
\text { al }^{15}, 2013\end{array}$ & $407(125)$ & Case-control & $\begin{array}{l}1987- \\
2004\end{array}$ & France & $\begin{array}{l}\text { Recurrence } \\
\text { /Progression }\end{array}$ & $\begin{array}{l}\text { Median } \\
11.14(1.19- \\
23.8) \text { year }\end{array}$ & Size, types, dan grade & $\begin{array}{l}\text { Government } \\
\text { grant }\end{array}$ \\
\hline 5 & $\begin{array}{l}\text { Kim et al } \\
2016\end{array}$ & $167(28)$ & Case-control & $\begin{array}{l}2011- \\
2013\end{array}$ & $\begin{array}{l}\text { South } \\
\text { Korea }\end{array}$ & Recurrence & 48 month & $\begin{array}{l}\text { Size, invasiveness, } \\
\text { mitosis, Ki-67, p53, } \\
\text { and postoperative } \\
\text { residue }\end{array}$ & Personal \\
\hline 6 & $\begin{array}{l}\text { Jang et } \\
\mathrm{al}^{29}, 2016\end{array}$ & $331(92)$ & $\begin{array}{l}\text { Retrospective } \\
\text { Cohort }\end{array}$ & $\begin{array}{l}1998- \\
2014\end{array}$ & $\begin{array}{l}\text { South } \\
\text { Korea }\end{array}$ & Progression & $\begin{array}{l}\text { Mean } 65.3 \\
(24.2- \\
131.1) \\
\text { month }\end{array}$ & $\begin{array}{l}\text { Size, invasiveness, Ki- } \\
67 \text {, and postoperative } \\
\text { residue }\end{array}$ & $\begin{array}{l}\text { Samsung } \\
\text { Biomedical } \\
\text { Research } \\
\text { Institute } \\
\text { grant }\end{array}$ \\
\hline 7 & $\begin{array}{l}\text { Raverot et } \\
\text { al }^{17}, 2017\end{array}$ & 213(89) & Cohort & $\begin{array}{l}2007- \\
2012\end{array}$ & France & Recurrence & $\begin{array}{l}\text { Mean } 3.5 \\
(+/-1.9) \\
\text { year }\end{array}$ & Size, types, dan grade & $\begin{array}{l}\text { Government } \\
\text { grant }\end{array}$ \\
\hline 8 & $\begin{array}{l}\text { Lv et } \mathrm{al}^{20} \\
2018\end{array}$ & $270(77)$ & Case-control & $\begin{array}{l}2008- \\
2016\end{array}$ & China & Recurrence & $\begin{array}{l}\text { Median } 44 \\
\text { (5-111) } \\
\text { month }\end{array}$ & $\begin{array}{l}\text { Size, types, subtypes, } \\
\text { invasiveness, } \\
\text { proliferative properties, } \\
\text { grade, and } \\
\text { postoperative residue }\end{array}$ & $\begin{array}{l}\text { Financial } \\
\text { support } \\
\text { from } \\
\text { government } \\
\text { hospitals }\end{array}$ \\
\hline 9 & $\begin{array}{l}\text { Hasanov et } \\
\mathrm{al}^{25}, 2019\end{array}$ & 117(39) & Case-control & $\begin{array}{l}2001- \\
2015\end{array}$ & Turkey & Recurrence & $\begin{array}{l}\text { Mean } 49.7 \\
+/-31.1 \\
\text { month }\end{array}$ & $\begin{array}{l}\text { Size, types, } \\
\text { invasiveness, mitosis, } \\
\text { Ki-67, and p53 }\end{array}$ & - \\
\hline 10 & $\begin{array}{l}\text { Guaraldi et } \\
\mathrm{al}^{30}, 2020\end{array}$ & 1066(116) & Case-control & $\begin{array}{l}1998- \\
2018\end{array}$ & Italy & Recurrence & $\begin{array}{l}\text { Mean } 65.6 \\
(1.0-160.2) \\
\text { month }\end{array}$ & $\begin{array}{l}\text { Size, types, } \\
\text { invasiveness, mitosis, } \\
\text { Ki-67, p53, and grade }\end{array}$ & $\begin{array}{l}\text { University } \\
\text { grant }\end{array}$ \\
\hline
\end{tabular}


Table 2

Quality assessment of selected case-control study design using NOS

\begin{tabular}{|c|c|c|c|c|c|c|c|c|c|}
\hline \multirow[t]{2}{*}{ Study (year) } & \multicolumn{4}{|l|}{ Selection } & \multirow{2}{*}{$\begin{array}{l}\text { Comparability } \\
\text { Comparability of } \\
\text { cases and controls } \\
\text { on the basis of the } \\
\text { design or analysis }\end{array}$} & \multicolumn{3}{|l|}{ Exposure } & \multirow[t]{2}{*}{ Total } \\
\hline & $\begin{array}{l}\text { Is the } \\
\text { case } \\
\text { definition } \\
\text { adequate }\end{array}$ & $\begin{array}{l}\text { Representati- } \\
\text { veness of } \\
\text { the case }\end{array}$ & $\begin{array}{l}\text { Selection } \\
\text { of } \\
\text { controls }\end{array}$ & $\begin{array}{l}\text { Definition } \\
\text { of } \\
\text { controls }\end{array}$ & & $\begin{array}{l}\text { Ascertainment } \\
\text { of exposure }\end{array}$ & $\begin{array}{l}\text { Same method } \\
\text { of } \\
\text { ascertainment } \\
\text { for cases and } \\
\text { controls }\end{array}$ & $\begin{array}{l}\text { Non- } \\
\text { response } \\
\text { rate }\end{array}$ & \\
\hline Hsu (1993) & * & * & * & * & & * & * & * & 7 \\
\hline $\begin{array}{l}\text { Gejman } \\
(2008)\end{array}$ & * & & * & * & * & * & * & * & 7 \\
\hline $\begin{array}{l}\text { Matsuyama } \\
(2012)\end{array}$ & * & * & * & * & & * & * & * & 7 \\
\hline $\begin{array}{l}\text { Trouillas } \\
\text { (2013) }\end{array}$ & * & & * & & * & * & * & * & 6 \\
\hline Kim (2016) & * & * & * & & * & * & * & * & 7 \\
\hline $\begin{array}{l}\text { Liang } \\
\text { (2018) }\end{array}$ & * & & * & & * & * & * & * & 6 \\
\hline $\begin{array}{l}\text { Hasanov } \\
(2019)\end{array}$ & * & & * & & * & * & * & & 5 \\
\hline $\begin{array}{l}\text { Guaraldi } \\
(2020)\end{array}$ & * & * & * & & * & * & * & * & 7 \\
\hline
\end{tabular}

Table 3

Quality assessment of selected cohort study design using NOS

\begin{tabular}{|c|c|c|c|c|c|c|c|c|c|}
\hline \multirow{2}{*}{$\begin{array}{l}\text { Study } \\
\text { (year) }\end{array}$} & \multicolumn{4}{|l|}{ Selection } & \multirow{2}{*}{$\begin{array}{l}\text { Comparability } \\
\text { Comparability } \\
\text { of cohorts on } \\
\text { the basis of } \\
\text { the design or } \\
\text { analysis }\end{array}$} & \multicolumn{3}{|l|}{ Outcome } & \multirow[t]{2}{*}{ Total } \\
\hline & $\begin{array}{l}\text { Representativeness } \\
\text { of the exposed } \\
\text { cohort }\end{array}$ & $\begin{array}{l}\text { Selection } \\
\text { of the } \\
\text { non } \\
\text { exposed } \\
\text { cohort }\end{array}$ & $\begin{array}{l}\text { Ascertainment } \\
\text { of exposure }\end{array}$ & $\begin{array}{l}\text { Demonstration } \\
\text { that outcome } \\
\text { of interest was } \\
\text { not present at } \\
\text { start of study }\end{array}$ & & $\begin{array}{l}\text { Assessement } \\
\text { of outcome }\end{array}$ & $\begin{array}{l}\text { Was } \\
\text { follow-up } \\
\text { long } \\
\text { enough } \\
\text { for } \\
\text { outcomes } \\
\text { to occur }\end{array}$ & $\begin{array}{l}\text { Adequacy } \\
\text { of follow- } \\
\text { up of } \\
\text { cohorts }\end{array}$ & \\
\hline $\begin{array}{l}\text { Jang } \\
(2016)\end{array}$ & * & * & * & * & * & * & * & * & 8 \\
\hline $\begin{array}{l}\text { Raverot } \\
(2017)\end{array}$ & * & * & * & * & * & * & * & & 7 \\
\hline
\end{tabular}

\section{Discussion}

The meta-analysis revealed a significant difference in the aggressiveness of the adenoma size $\geq 10 \mathrm{~mm}$. The results of the meta-analysis support this by comparing the mean size of the adenoma and giant adenoma, both of which showed significant aggressiveness, with mean differences of 5.61 (3.29-

7.92) and OR 2.21 (1.17-4.18), respectively (figure L2 and L3). The findings of Liang Lv et al. ${ }^{20}$ study, which compared adenomas' diameter and volume, are also intriguing. The findings were surprising because, despite a significant mean difference in diameter, there was no clinical difference $(3.42 \pm 1.08 \mathrm{~cm}$ and $2.80 \pm 0.84 \mathrm{~cm}, \mathrm{p}<0.0001)$. When measured by volume, however, there is a clinically significant difference $\left(12.1(0.06-76.20) \mathrm{cm}^{3}\right.$ and $\left.6.00(0.05-50.60) \mathrm{cm}^{3}, \mathrm{p}<0,0001\right)$. This finding could help to reduce the risk of bias or error when measuring adenoma diameter.

The corticotroph type was more aggressive than the other types, while the somatotroph type was less aggressive. Figure L7 depicts the results of other types of meta-analysis. There are currently no guidelines that could determine which type of pituitary adenoma is more aggressive than the other. However, two of the five high-risk subtypes highlighted by WHO, namely crook's cell adenoma and silent corticotroph adenoma, are found to be part of the corticotroph type. ${ }^{19}$ The small number of studies evaluating this subtype could be due to the WHO's relatively recent recommendation in 2017 or certain difficulties in the examination, which is quite detailed and costly. However, as recommended by WHO, this should still be considered when evaluating patients with pituitary adenoma. ${ }^{19,21}$

In the case-control meta-analysis, the invasive trait variable showed a significant difference in aggressiveness. The significance of invasiveness could be seen through the assessment of grade $2 \mathrm{a}$, which showed significant differences in aggressiveness compared to grade $1 \mathrm{a}$ in the Jang et al. ${ }^{29}$ study and similarly in the Raverot et al. ${ }^{17}$ study. Pituitary adenomas and other neoplastic diseases have long been assessed using this invasive technique. Based on Hardy and Knosp, pituitary adenoma is divided into two categories based on the level of invasion. ${ }^{32,33}$ In general, a higher level of invasion makes it more difficult for the surgeon to remove the mass completely, increasing the risk of the adenoma becoming aggressive. ${ }^{11}$ In 2004 , WHO recommended the classification of atypical pituitary adenomas where it prioritizes proliferative properties over invasiveness in predicting pituitary adenomas' 
aggressiveness. ${ }^{18}$ Experts at the time were outraged, and this drew much criticism. The WHO abolished the atypical classification in 2017 after it was proven that many patients do not have proliferative traits but have an aggressive outcome. ${ }^{19,21}$

On the aggressiveness, the proliferative trait variable showed significance in the meta-analysis result. Because it requires a combination of two positives from three IHC tests (Ki-67, p53, and mitosis), each of these components is predicted to have a prognostic value for the aggressiveness of pituitary adenoma, this proliferative property has a fairly strong prognostic value.

The variable Ki-67 showed a significant meta-analysis result on the aggressiveness. This is also supported by the meta-analysis results of the mean aggressiveness difference, which shows a significant difference of 1.05 (0.87-1.22)\% (Figure L4). No meta-analysis could be performed in the cohort study group; however, Jang et al. ${ }^{27}$ found that aggressiveness was associated with higher Ki-67 values. This procedure has long been used to diagnose endocrine tumors, particularly pituitary adenomas. Guadagno E et al. ${ }^{31}$ conducted a fairly large study on the significance of Ki-67 in pituitary adenomas, with mixed results. Ki-67 is one component in assessing the proliferative nature of pituitary adenoma, according to WHO guidelines, so it must be combined with other markers to provide a better prognostic value. ${ }^{18,19,21}$

In one of the three studies that looked at it, the variable of mitosis rate showed a significant difference in aggressiveness. Three studies with significant results on the aggressiveness were meta-analyzed.

In one of the four studies that looked at it, the p53 variable showed a significant difference in aggressiveness. A positive p53 was found to significantly impact the aggressiveness in the meta-analysis.

The variable of adenoma's grade showed significant aggressiveness at grade $2 \mathrm{~b}$. The findings of a meta-analysis comparing grades $2 \mathrm{~b}$ and $1 \mathrm{a}$ with significant differences in aggressiveness back this up (figure L5). Although no meta-analysis could be performed in a cohort study, Raverot et al. ${ }^{17}$ found aggressive aggression at grade $2 \mathrm{~b}$ versus grade $1 \mathrm{a}$. Trouillas et al. ${ }^{15}$ proposed this grade in their study evaluating prognostic factors for pituitary adenoma postoperative outcome. This grade is based on pituitary adenomas' invasive and proliferative nature, both of which have long been used to predict its' prognosis. The higher the grade, the more positive prognostic factors there are, so this assessment becomes objective and means that the postoperative outcome is quite good.

Because it has been extensively studied in the selected literature, the postoperative residue is an additional component that is quite important in assessing the aggressiveness of postoperative pituitary adenomas. In studies that looked at the tendency to occur in adenomas with postoperative residues, this component showed significant differences in aggressiveness. This component is commonly used to assess postoperative outcomes in other organ malignancies. On patients where gross total resection cannot be performed, the unclean removal of the mass tissue will result in future recurrence. The meta-analysis found that aggressiveness was significantly increased in the presence of postoperative residues, with an OR of 2.86 (1.326.19). (Fig. L6).

The limitations include:

1. Wide range of study designs

2. The number of independent variables studied and research subjects.

3. The study's quality

4. Differences in definitions and variable data types resulted in a separated meta-analysis of each variable between studies with case-control and cohort designs.

5. The limited number of studies.

According to an assessment of case-control study quality, four studies had poor quality, and five studies had an unclear definition of control, indicating a selection bias possibility from the included studies. Meanwhile, the cohort study's quality assessment revealed a high dropout rate for no apparent reason, indicating the possibility of study outcome bias. The proliferative trait variable is one of the components of adenoma grade, where an anatomical pathology examination relies on the subjective assessment of anatomical pathologists-only one anatomical pathologist is examining in the studies, so the chance of assessment bias is there. Because pituitary adenoma has a low incidence, there may be unpublished studies. This publication bias could also be due to limited access to large databases like Embase.

\section{Conclusion}

The aggressiveness of postoperative pituitary adenomas is influenced by clinicopathological factors such as adenoma size, adenoma type/subtype, invasiveness, proliferative nature (Ki-67, mitotic rate, and $\mathrm{p53})$, and adenoma grade.

\section{Recommendations}

To compare high-risk and low-risk adenoma subtypes to postoperative pituitary adenoma aggressiveness and develop a scoring system to predict postoperative pituitary adenoma aggressiveness.

\section{Abbreviations}


PitNET: pituitary neuroendocrine tumor; IHC: immunohistochemical; ESE: European Society of Endocrinology; WHO: World Health Organization; PICO:

Patients/Problem, Intervention, Comparison, and Outcome; NOS: Newcastle Ottawa Scale.

\section{Declarations}

\section{Consent Form}

Not applicable.

\section{Ethical and consent}

Not applicable.

\section{Funding}

This research received no specific grant from any funding agency in the public, commercial, or not-for-profit sectors

\section{Authors' contribution}

Idea, study design: TJET, HAA, JK; Data collection and analysis: TJET, HAA, JK; Writing draft for publication: TJET, HAA

\section{Acknowledgement}

The authors would like to thank Nida Amalina, and Mellisa Evelyn for all the technical helps of this project.

\section{Competing Interest}

The authors have no conflict of interest to disclose in this meta-analysis.

\section{References}

1. Trouillas J, Jaffrain-Rea ML, Vasiljevic A, Raverot G, Roncaroli F, Villa C C. How to classify the pituitary neuroendocrine tumors (PitNET)s in 2020. Cancers (Basel). 2020;12(2):1-17

2. Asa SL, Asioli S, Bozkurt S, Casar-Borota O, Chinezu L, Comunoglu N, et al. Pituitary neuroendocrine tumors (PitNETs): nomenclature evolution, not clinical revolution. Pituitary [Internet]. 2020;23(3):322-5. Available from: https://doi.org/10.1007/s11102-019-01015-0

3. Dorsey JF, Hollander AB, Alonso-Basanta M, Macyszyn L, Bohman LE, Judy KD, et al. Cancer of the Central Nervous System [Internet]. Sixth Edit. Abeloff's Clinical Oncology: Fifth Edition. Elsevier Inc.; 2013. 908-965 p. Available from: https://doi.org/10.1016/B978-0-323-47674-4.00063-3

4. Melmed S, Kleinberg D. Chapter 9 - Pituitary Masses and Tumors [Internet]. Thirteenth. Williams Textbook of Endocrinology. Philadelphia: Elsevier Inc.; 2016. 232-299 p. Available from: https://doi.org/10.1016/B978-0-323-29738-7.00009-5

5. Shibui S. Report of brain tumor registry of Japan (2001-2004). Vol. 54, Neurologia medico-chirurgica. 2013. 2001-2004 p.

6. Park K, Choi J, Park SH, Nam JY, Song SO, Song YD, et al. Prevalence and Incidence of pituitary tumors: a nation-wide Population-based study using Korean National Health Insurance claims data. Endocr Abstr [Internet]. 2017 May 3; Available from: http://www.endocrineabstracts.org/ea/0049/ea0049ep960.htm

7. Fernandez A, Karavitaki N, Wass JAH. Prevalence of pituitary adenomas: A community-based, cross-sectional study in Banbury (Oxfordshire, UK). Clin Endocrinol (Oxf). 2010;72(3):377-82.

8. Betella N, Tresoldi A, Carosi G, Sindaco G Del, Locatelli M, Mazziotti G, et al. Characteristics and natural history of a large cohort of non-functioning pituitary incidentalomas: a two-centers study. Endocr Abstr [Internet]. 2019;GP236. Available from: https://www.endocrineabstracts.org/ea/0063/ea0063gp236.htm

9. Melmed S. Pituitary-tumor endocrinopathies. N Engl J Med. 2020;382(10):937-50.

10. Chatzellis E, Alexandraki KI, Androulakis II, Kaltsas G. Aggressive pituitary tumors. Neuroendocrinology. 2015;101(2):87-104.

11. Meij BP, Lopes M-BS, Ellegala DB, Alden TD, Laws ERJ. The long-term significance of microscopic dural invasion in 354 patients with pituitary adenomas treated with transsphenoidal surgery. J Neurosurg. 2002 Feb;96(2):195-208.

12. McCormack A, Dekkers O, Petersenn S, Popovic V, Trouillas J, Raverot G. Treatment of aggressive pituitary tumours and carcinomas: Results of a European Society of Endocrinology (ESE) survey 2016. Eur J Endocrinol [Internet]. 2018;178(3):265-76. Available from: http://www.embase.com/search/results?subaction=viewrecord\&from=export\&id=L621419956\%0Ahttp://dx.doi.org/10.1530/EJE-17-0933

13. Trouillas J, Burman P, McCormack A, Petersenn S, Popovic V, Dekkers O, et al. Aggressive pituitary tumours and carcinomas: Two sides of the same coin? Eur J Endocrinol. 2018;178(6):C7-9.

14. Raverot G, Burman P, McCormack A, Heaney A, Petersenn S, Popovic V, et al. European Society of Endocrinology Clinical Practice Guidelines for the management of aggressive pituitary tumours and carcinomas. Eur J Endocrinol [Internet]. 2018 Jan;178(1):G1-24. Available from:

https://eje.bioscientifica.com/view/journals/eje/178/1/EJE-17-0796.xml 
15. Trouillas J, Roy P, Sturm N, Dantony E, Cortet-Rudelli C, Viennet G, et al. A new prognostic clinicopathological classification of pituitary adenomas: A multicentric case-control study of 410 patients with 8 years post-operative follow-up. Acta Neuropathol. 2013;126(1):123-35.

16. Asioli S, Righi A, lommi M, Baldovini C, Ambrosi F, Guaraldi F, et al. Validation of a clinicopathological score for the prediction of post-surgical evolution of pituitary adenoma: retrospective analysis on 566 patients from a tertiary care centre. Eur J Endocrinol. 2019;180(2):127-34.

17. Raverot G, Dantony E, Beauvy J, Vasiljevic A, Mikolasek S, Borson-Chazot F, et al. Risk of recurrence in pituitary neuroendocrine tumors: A prospective study using a five-tiered classification. J Clin Endocrinol Metab. 2017;102(9):3368-74.

18. Al-Shraim M, Asa SL. The 2004 World Health Organization classification of pituitary tumors: What is new? Acta Neuropathol. 2006;111(1):1-7.

19. Mete O, Lopes MB. Overview of the 2017 WHO Classification of Pituitary Tumors. Endocr Pathol. 2017;28(3):228-43.

20. Lv L, Yin S, Zhou P, Hu Y, Chen C, Ma W, et al. Clinical and Pathologic Characteristics Predicted the Postoperative Recurrence and Progression of Pituitary Adenoma: A Retrospective Study with 10 Years Follow-Up. World Neurosurg. 2018;118:e428-35.

21. Nishioka H, Inoshita N. New WHO classification of pituitary adenomas (4th edition): assessment of pituitary transcription factors and the prognostic histological factors. Brain Tumor Pathol. 2018;(January):1-5.

22. Lüdecke DK, Buchfelder M, Fahlbusch R, Quabbe HJ, Petersenn S, Saeger W. Pathohistological classification of pituitary tumors: 10 years of experience with the German Pituitary Tumor Registry. Eur J Endocrinol. 2007;156(2):203-16.

23. Kovacs K, Rotondo F, Horvath E, Syro L V., Di leva A, Cusimano MD, et al. Letter to the Editor. Endocr Pathol. 2015;26(1):93-4.

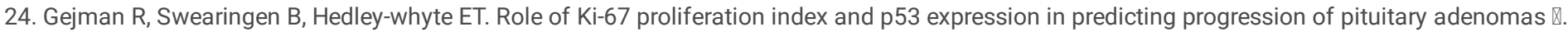
2008;758-66.

25. Hasanov R, Berna İ, Kiremitçi S, Erden E, Güllü S. The Prognostic Roles of the Ki-67 Proliferation Index, P53 Expression, Mitotic Index, and Radiological Tumor Invasion in Pituitary Adenomas. 2019;49-55.

26. Liu J, He Y, Zhang X, Yan X, Huang Y. Clinicopathological analysis of 250 cases of pituitary adenoma under the new WHO classification. 2020;1890-8.

27. Jang JH, Kim KH, Lee YM, Kim JS, Kim YZ. Surgical Results of Pure Endoscopic Endonasal Transsphenoidal Surgery for 331 Pituitary Adenomas: A 15-Year Experience from a Single Institution. World Neurosurg [Internet]. 2016;96:545-55. Available from:

http://dx.doi.org/10.1016/j.wneu.2016.09.051

28. Hardy J. Transphenoidal microsurgery of the normal and pathological pituitary. Clin Neurosurg. 1969;16:185-217.

29. Knosp E, Steiner E, Kitz K, Matula C. Pituitary adenomas with invasion of the cavernous sinus space: a magnetic resonance imaging classification compared with surgical findings. Neurosurgery. 1993 Oct;33(4):610-8.

30. Wolfsberger S, Knosp E. Comments on the WHO 2004 classification of pituitary tumors. Acta Neuropathol [Internet]. 2006;111(1):66-7. Available from: https://doi.org/10.1007/s00401-005-1097-2

31. Guadagno E, D’Avella E, Cappabianca P, Colao A, Del Basso De Caro M. Ki67 in endocrine neoplasms: to count or not to count, this is the question! A systematic review from the English language literature. J Endocrinol Invest [Internet]. 2020; Available from: https://doi.org/10.1007/s40618-02001275-9

32. Oruçkaptan HH, Senmevsim Ö, Özcan OE, Özgen T. Pituitary adenomas: Results of 684 surgically treated patients and review of the literature. Surg Neurol. 2000;53(3):211-9.

33. Pereira AM. Clinical factors involved in the recurrence of pituitary adenomas after surgical remission: a structured review and meta-analysis. 2012;71-83.

34. Adenomlar H, Elde T, Prognostik E. Prognostic Factors Obtained from Long-Term Follow-up of Pituitary Adenomas and Other Sellar Tumors. 2013;679-87.

35. Chiloiro S, Bianchi A, Doglietto F, Waure C De. Radically resected pituitary adenomas: prognostic role of Ki 67 labeling index in a monocentric retrospective series and literature review. 2014;267-76.

36. Waraasawapati S, Chaisuriya N, Daungthongpon P, Jingjit K, Kitkuandee A, Thanapaisal C. C opyright @ Royal College of pathologists of Australasia. Unauthorized reproduction of this article is prohibited. Pathology [Internet]. 2014;46:S118. Available from: http://dx.doi.org/10.1097/01.PAT.0000454501.50061.1f

37. Bodhinayake I, Ottenhausen M, Mooney MA, Kesavabhotla K, Christos P, Schwarz JT, et al. Results and risk factors for recurrence following endoscopic endonasal transsphenoidal surgery for pituitary adenoma. Clin Neurol Neurosurg [Internet]. 2014;119:75-9. Available from: http://dx.doi.org/10.1016/j.clineuro.2014.01.020

38. Sarkar S, Chacko AG, Chacko G. Clinicopathological correlates of extrasellar growth patterns in pituitary adenomas. J Clin Neurosci [Internet]. 2015;22(7):1173-7. Available from: http://dx.doi.org/10.1016/j.jocn.2015.01.029

39. Lv L, Hu Y, Yin S, Wang M, Zhou P, Zhang N. Clinically aggressive phenotype: A clinicopathological case series of atypical pituitary adenomas. 2018;167(37):93-8.

40. Petry C, Henrique J, Poli Z, Dossin IDA, Garcia C, Leães S, et al. Evaluation of the potential of the Ki67 index to predict tumor evolution in patients with pituitary adenoma. 2019;12(1):320-6.

41. Pappy AL, Savinkina A, Bicknese C, Neill S, Oyesiku NM, loachimescu AG. Predictive modeling for pituitary adenomas: single center experience in 501 consecutive patients. Pituitary [Internet]. 2019;22(5):520-31. Available from: https://doi.org/10.1007/s11102-019-00982-8

Page $9 / 13$ 
Figures

$\geq 10 \mathrm{~mm} \quad<10 \mathrm{~mm} \quad$ Odds Ratio

Study or Subgroup

Hsu, et al. 1993

Gejman, et al. 2008

Matsuyama, et al. 2012

Trouillas, et al. 2013

Kim, et al. 2016

Hasanov, et al. 2019

Guaraldi, et al. 2020

Total $(95 \% \mathrm{Cl})$

Total events

Heterogeneity: $\mathrm{Chi}^{2}=7.70, \mathrm{df}=6(\mathrm{P}=0.26) ; \mathrm{I}^{2}=22 \%$

Test for overall effect: $Z=3.48(P=0.0005)$
Events Total Events Total Weight M-H, Fixed, $95 \% \mathrm{Cl}$ Year

$\begin{array}{lllllll}29 & 50 & 1 & 12 & 1.1 \% & 15.19[1.82,126.90] & 1993\end{array}$

$\begin{array}{lllllll}21 & 44 & 3 & 11 & 4.2 \% & 2.43[0.57,10.41] & 2008\end{array}$

$\begin{array}{lllllll}12 & 38 & 0 & 1 & 1.1 \% & 1.42[0.05,37.25] & 2012\end{array}$

$\begin{array}{lllllll}108 & 313 & 17 & 94 & 28.5 \% & 2.39[1.34,4.24] & 2013\end{array}$

$\begin{array}{lllllll}26 & 152 & 2 & 15 & 5.0 \% & 1.34[0.29,6.30] & 2016\end{array}$

$\begin{array}{lllllll}34 & 99 & 5 & 18 & 9.3 \% & 1.36[0.45,4.13] & 2019\end{array}$

$\begin{array}{lllllll}94 & 832 & 22 & 234 & 50.8 \% & 1.23[0.75,2.00] & 2020\end{array}$

$1528 \quad 385 \quad 100.0 \% \quad 1.79[1.29,2.48]$

$324 \quad 50$

Odds Ratio

M-H, Fixed, $95 \% \mathrm{Cl}$

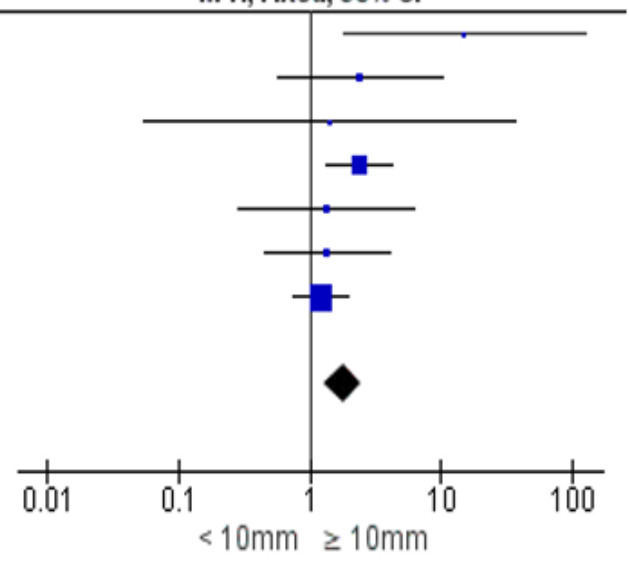

\section{Figure 1}

Forest plot of adenoma size $\geq 10 \mathrm{~mm}$ with adenoma size $<10 \mathrm{~mm}$ on aggressiveness (case-control study)

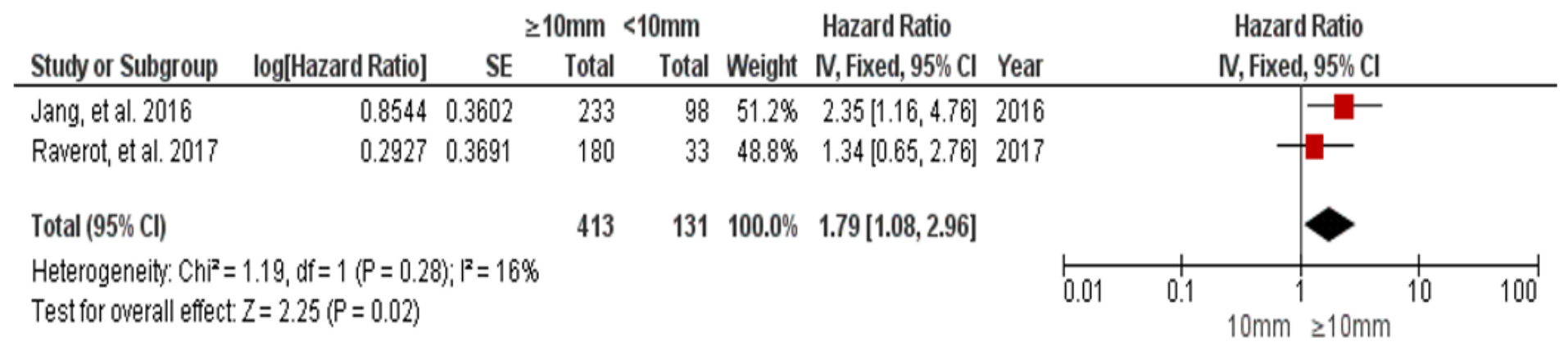

\section{Figure 2}

Forest plot of adenoma size $\geq 10 \mathrm{~mm}$ with adenoma size $<10 \mathrm{~mm}$ on aggressiveness (cohort study) 


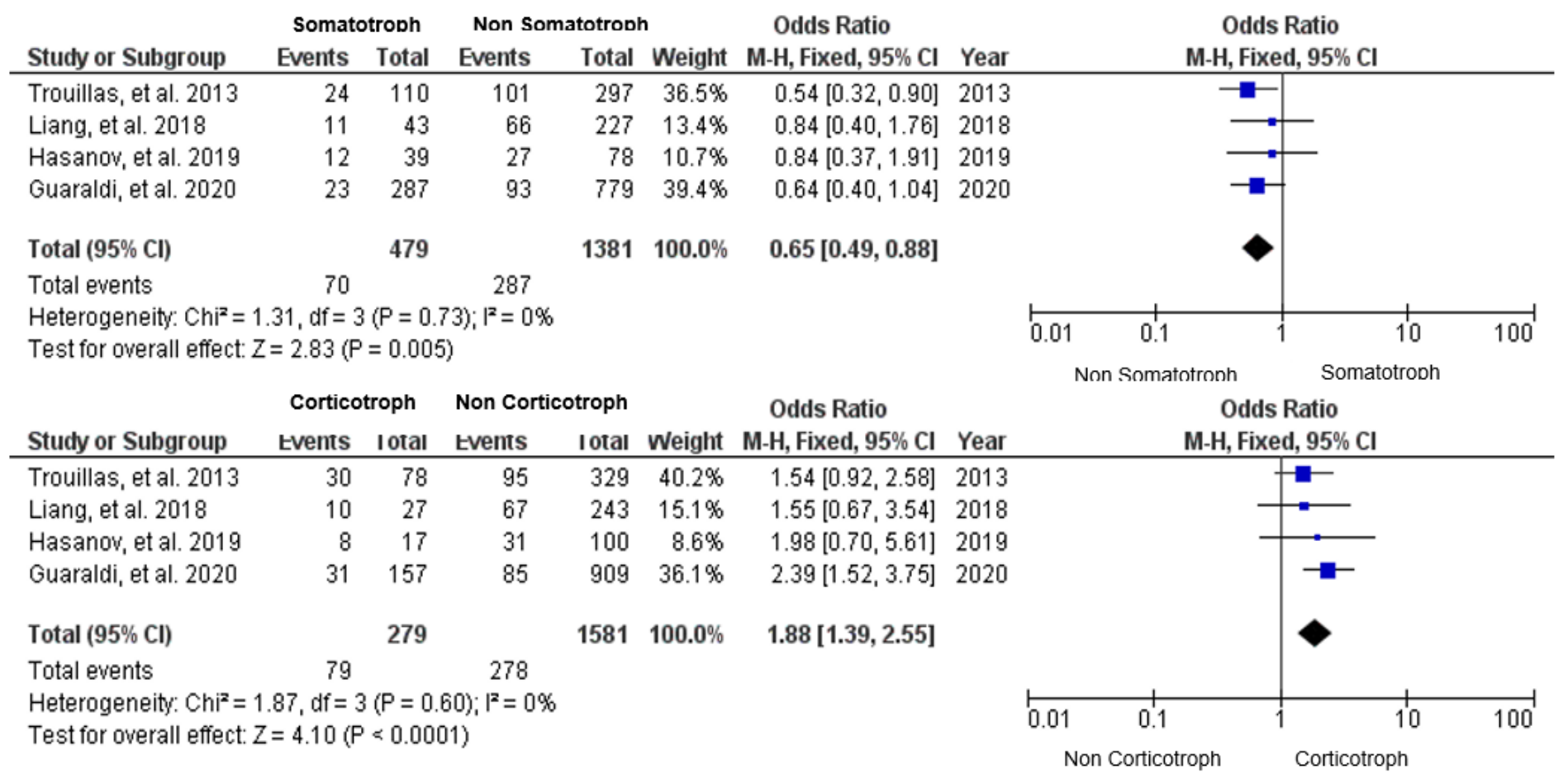

Figure 3

A forest plot of aggressiveness based on adenoma type (somatotroph and corticotroph)

Invasive Non Invasive Odds Ratio

Study or Subgroup Events Total Events Total Weight M-H, Fixed, $95 \% \mathrm{Cl}$ Year

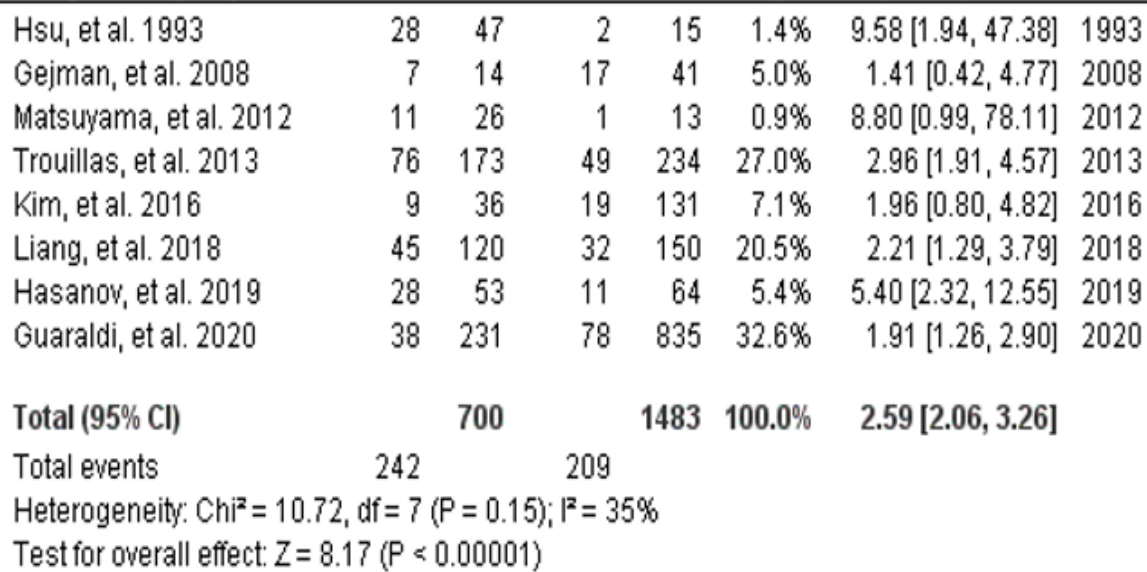

Test for overall effect: $Z=8.17(P<0.00001)$
Odds Ratio

M-H, Fixed, $95 \% \mathrm{Cl}$

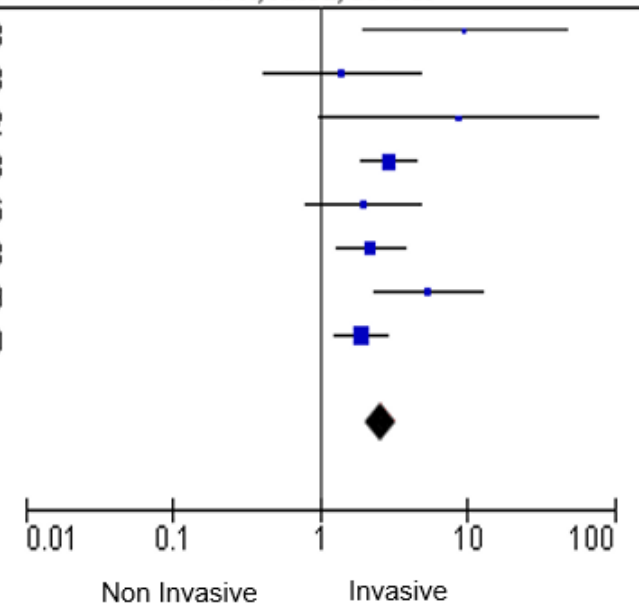

Figure 4

A forest plot of invasive and non-invasive properties on aggressiveness 


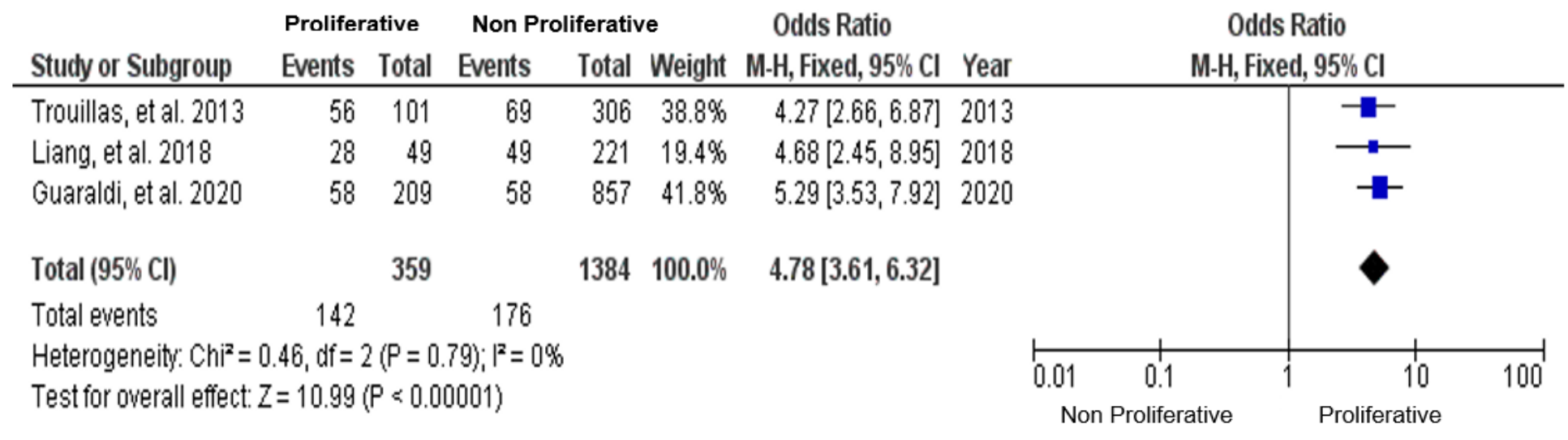

Figure 5

Forest plot of proliferative and non-proliferative traits on aggressiveness

\section{Ki- $67 \geq 3 \% \quad$ Ki- $67<3 \% \quad$ Odds Ratio}

Study or Subgroup Events Total Events Total Weight M-H, Fixed, $95 \% \mathrm{Cl}$ Year

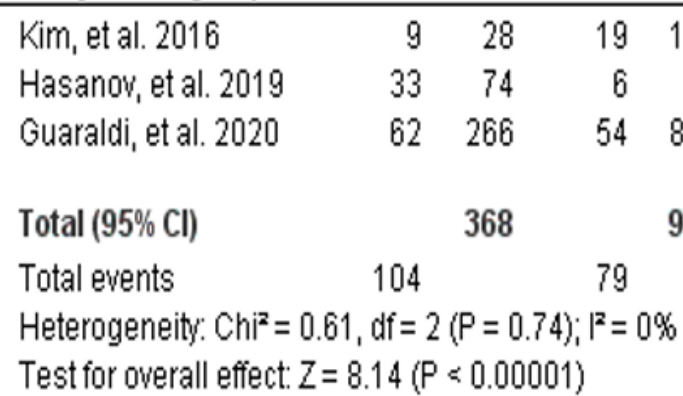

Heterogeneity: Chi $^{2}=0.61, d f=2(P=0.74) ;$
Test for overall effect: $Z=8.14(P<0.00001)$
Odds Ratio

M-H, Fixed, $95 \% \mathrm{Cl}$

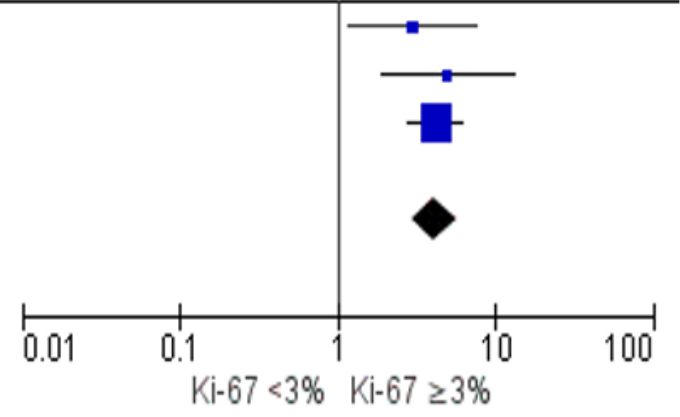

Figure 6

Forest plot of $\mathrm{Ki}-67 \geq 3$ with $\mathrm{Ki}-67<3$ on aggressiveness

\begin{tabular}{|c|c|c|c|c|c|c|c|c|c|c|c|}
\hline \multirow[b]{2}{*}{ Study or Subgroup } & \multicolumn{2}{|c|}{ Mitosis >2 } & \multicolumn{2}{|c|}{ Mitosis $\leq 2$} & \multicolumn{3}{|c|}{ Odds Ratio } & \multirow{2}{*}{\multicolumn{4}{|c|}{$\begin{array}{l}\text { Odds Ratio } \\
\text { M-H, Random, } 95 \% \mathrm{Cl}\end{array}$}} \\
\hline & Events & Total & Events & Total & Weight & M-H, Random, $95 \% \mathrm{Cl}$ & Year & & & & \\
\hline Kim, et al. 2016 & 3 & 7 & 25 & 160 & $21.4 \%$ & $4.05[0.85,19.21]$ & 2016 & & & & \\
\hline Hasanov, et al. 2019 & 19 & 47 & 12 & 36 & $34.0 \%$ & $1.36[0.55,3.36]$ & 2019 & & & & \\
\hline Guaraldi, et al. 2020 & 55 & 195 & 61 & 871 & $44.7 \%$ & $5.22[3.48,7.83]$ & 2020 & & & & \\
\hline Total $(95 \% \mathrm{Cl})$ & & 249 & & 1067 & $100.0 \%$ & $3.13[1.19,8.20]$ & & & & & \\
\hline Total events & 77 & & 98 & & & & & & & & \\
\hline \multicolumn{8}{|c|}{$\begin{array}{l}\text { Heterogeneity: } \operatorname{Tau}^{2}=0.50 ; \mathrm{Chi}^{2}=7.17, \mathrm{df}=2(P=0.03) ; \mathrm{I}^{2}=72 \% \\
\text { Test for overall effect: } Z=2.32(P=0.02)\end{array}$} & 0.01 & 0.1 Mitosis $\leq 2$ & Mitosis $>2$ & 100 \\
\hline
\end{tabular}

Figure 7

Forest plot of mitotic rate $>2$ with mitotic rate $\leq 2$ on aggressiveness 
p53 Positive p53 Negative

Odds Ratio

Odds Ratio

Study or Subgroup Events Total Events Total Weight $\mathrm{M}-\mathrm{H}$, Fixed, $95 \% \mathrm{Cl}$ Year

M-H, Fixed, 95\% Cl

$\begin{array}{lrrrrrrr}\text { Gejman, et al. 2008 } & 3 & 6 & 21 & 49 & 7.9 \% & 1.33[0.24,7.28] & 2008 \\ \text { Kim, et al. 2016 } & 0 & 5 & 26 & 162 & 5.9 \% & 0.47[0.03,8.72] & 2016 \\ \text { Hasanov, et al. 2019 } & 3 & 8 & 28 & 72 & 12.0 \% & 0.94[0.21,4.26] & 2019 \\ \text { Guaraldi, et al. 2020 } & 32 & 169 & 84 & 897 & 74.2 \% & 2.26[1.45,3.53] & 2020 \\ & & & & & & & \\ \text { Total (95\% Cl) } & & 188 & & 1180 & \mathbf{1 0 0 . 0 \%} & 1.92[1.28,2.90] \\ \text { Total events } & 38 & & 159 & & & \end{array}$

Heterogeneity: $\mathrm{Chi}^{2}=2.44, \mathrm{df}=3(\mathrm{P}=0.49) ; \mathrm{I}^{2}=0 \%$

Test for overall effect: $Z=3.13(P=0.002)$

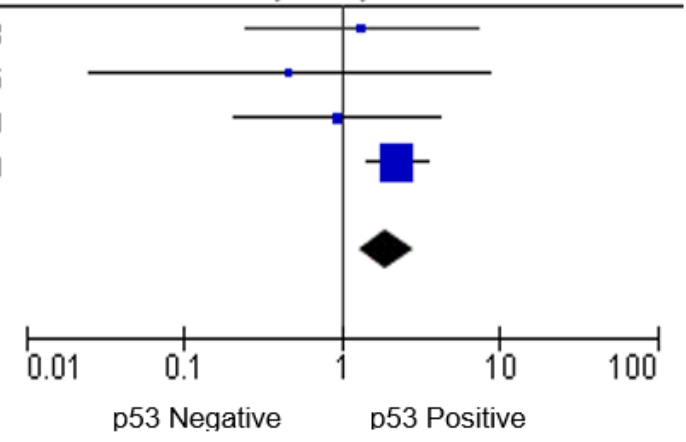

Figure 8

Forest plot of $\mathrm{p} 53$ positive with $\mathrm{p} 53$ negative on aggressiveness

Grade 2b Grade Non $2 b$

Study or Subgroup

Trouillas, et al. 2013

Guaraldi, et al. 2020

Total $(95 \% \mathrm{Cl})$

Total events

Heterogeneity: $\mathrm{Ch}^{2}=0.52, \mathrm{df}=1(P=0.47) ;\left.\right|^{2}=0 \%$

Test for overall effect: $Z=7.13$ ( $P<0.00001)$

Events Total Events

Total

86

$55 \quad 186$

Odds Ratio

Total

$34755.3 \%$

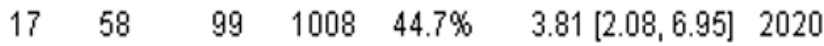

$55.3 \% \quad 5.16[2.89,9.21] 2013$

\section{$118 \quad 1355 \quad 100.0 \% \quad 4.56[3.00,6.91]$}

\section{Figure 9}

Forest plot of grade $2 \mathrm{~b}$ (invasive and proliferative) with grade non $2 \mathrm{~b}$ on aggressiveness

\section{Supplementary Files}

This is a list of supplementary files associated with this preprint. Click to download.

- Attachment.docx 